\title{
COHEN, BUBER, ROSENZWEIG, SCHOLEM Fyra tyska judar och första världskriget
}

\author{
Svante Lundgren \\ Pargas

I den allmänna uppfattningen om världshistorien är det det andra världskriget med allt vad det medförde som upplevs som århundradets civilisatoriska katastrof. Och det med rätta. Detta krig inte bara skördade mer offer än något krig före eller efter. Det introducerade atomvapnen, det förde med sig ett systematiskt folkmord utfört med industriell effektivitet och det gav till resultat en politiskt tudelad värld och ett kallt krig som skulle vara i drygt fyra decennier.

Men också det första världskriget var ett avgörande bakslag för det humanistiska framskridandet. Det gjorde slut på en epok av optimism och framstegstro. Ur det första världskrigets inferno såddes fröet till nästa krig lika väl som det gav upphov till de nya och med tiden förödande ideologierna fascism, nazism och kommunism. Den unga socialistiska rörelsen förlorade sin oskuld. Bara någon månad efter att socialistledarna kommit med gemensamma internationalistiska uttalanden emot upprustning och krig - arbetarna skall inte lyfta vapen emot andra länders arbetare - drogs de med i den patriotiska hysterin och stödde helhjärtat det egna landets krigföring. Endast ett fătal som Jean Jaurès i Frankrike och Rosa Luxemburg i Tyskland - höll fast vid det tidigare krigsmotståndet. ${ }^{1}$

För Europas judar var det första världskriget naturligtvis inte en sådan katastrof som det andra skulle bli. Men också detta krig blev en judisk prövning. Under I80o-talet hade judarna i de flesta av Europas länder fătt fulla medborgerliga rättigheter. Den framväxande reformjudendomen betonade att judarna utgör en religionsgemenskap inte en nation: man är fransman, tysk eller österrikare av mosaisk trosbekännelse. Andra delar av judenheten - och inte 
minst den unga sionistiska rörelsen - betonade åter judendomens nationella karaktär.

Den politiska antisemitismen anklagade judarna för s.k. dubbel lojalitet, dvs. för att känna större samhörighet med och lojalitet mot den världsvida judenheten än mot det land där de bor. Hur reagerade då judarna I9I4 då "fosterlandet kallade"? Var deras tyska eller franska eller engelska patriotism lika stor som deras icke-judiska grannars? Eller var de präglade av den mångomtalade judiska kosmopolitismen? ${ }^{2}$

När Theodor Herzl I897 sammankallade den första sionistiska världskongressen fördömdes projektet i skarpa ordalag av de tyska rabbinerna, både liberala och ortodoxa. Det hävdades att judarna med yttersta hängivenhet skall tjäna det land där de bor och att de känner sig helt ett med andra tyskar och att de därför eftersträvar det kära fosterlandets bästa med lika stor entusiasm. ${ }^{3}$ Den allmänna uppfattningen bland Tysklands judar - företrädda av det år I893 grundade Centralverein deutscher Staatsbürger jüdischen Glaubens - var att bejaka och betona sin tyskhet. De tyska sionisterna hade en annan inställning, men en brytning mellan dessa och Centralverein ägde rum först I9Io då en ny radikalare generation sionister stigit fram. När det världspolitiska läget tillspetsades publicerade de judiska ledarna i februari I9I4 helsidesannonser i allmänna tidningar där de underströk judarnas patriotism och samhörighet med Tyskland. ${ }^{4}$

I denna artikel skall jag granska hur fyra berömda tyska judar ställde sig till första världskriget. Två av dem - Hermann Cohen och Franz Rosenzweig var motståndare till sionismen, medan Martin Buber och Gershom Scholem var sionister.

\section{Hermann Cohen: superpatrioten}

Den berömde nykantianske filosofen Hermann Cohen (I842-I9I8) var vid världskrigets utbrott redan en gammal man. Han hade lyckats med det som ingen före honom gjort: att som jude nå en framstående position inom den tyska akademiska världen. Denna personliga framgång parad med en liberal optimistisk världssyn gjorde honom till en stor patriot. Trots en viss antisemitism var Tyskland enligt hans mening på väg att bli den humanistiska, liberala och toleranta nation som judarna hoppades på. Cohens skarpa avståndstagande från den judiska nationalismen och hans engagemang för socialismen, som ju i grunden är internationalistisk, hindrade honom inte från att vara tysk patriot. Han insåg farorna i all nationalism och det han hyllade var inte den tyska nationalismen utan den tyska staten. "Der Staatsbegriff ist der ethische Kulturbegriff." 
Efter att första världskriget brutit ut agerar Cohen aktivt på två fronter. Dels försöker han övertyga tyskarna om att judarna är lojala patrioter. Dels försöker han övertyga judarna i andra länder om att Tyskland är deras sanna moderland.

År 1915 skriver Cohen en appell till USA:s judar. USA var ännu neutralt och syftet med appellen är att få landets judar att agera mot en amerikansk inblandning i kriget. Cohen - som deklarerar att han skriver både som tysk och som jude - börjar med att förneka rykten om tyska grymheter. Sedan gör han en lång uppräkning av allt gott som Tyskland frambringat, ofta med aktivt deltagande av tyska judar. Moses Mendelsohn var tysk jude och den i USA så starka reformjudendomen härstammar från Tyskland. Genom emigration har tyska judar bidragit till utvecklingen i alla västerländska nationer. Därför borde alla västerländska judar vid sidan av sitt politiska fosterland (Vaterland) räkna Tyskland som sitt kulturella och religiösa moderland (Mutterland). Tysklands seger i kriget kommer att ge judarna i många länder mänskliga rättigheter och världen rättvisa och fred (Gerechtigkeit und Völkerfrieden). ${ }^{6}$

Cohen skrev också två pamfletter - "Deutschtum und Judentum" (I9IS respektive 1916) - riktade till den tyska befolkningen. Syftet med dessa är att visa den stora själsfrändskapen som existerar mellan tyskar och judar. ${ }^{7}$ Cohen tar fram exempel på detta från olika områden: filosofi, musik, statslära. Judisk monoteism motsvarar tysk idealism, den judiska lagen motsvarar Kants etik, den judiska messianismen motsvarar tysk socialism. Han upprepar tesen om att judarna i övriga länder känner stor tacksamhet och samhörighet med Tyskland, vilket inger hopp framför allt när det gäller USA:s agerande. Anti-tyska uttalanden av franska och engelska judar förklarar han som uttryck för blindhet och otacksamhet. Kriget kommer förhoppningsvis att betyda en förnyelse av den tyska nationen och lägga grunden för en varaktig fred i världen. "Der gerechte Krieg ist die Vorbereitung des ewigen Friedes."

Cohens första pamflett kritiserades inte bara av de yngre sionisterna utan också från tyskt-nationellt håll. Han skrev därför ett svar på denna kritik där han ytterligare betonade likheterna mellan judiskhet och tyskhet. Eftersom religionen inte längre är dogmbunden och eftersom judendom och kristendom överensstämmer när det gäller det etiska så är skillnaden mellan dessa båda religioner inte längre särskilt betydande. Judendomen etiska styrka (Kulturkraft) har haft stor betydelse för den tyska humanismen och idealistiska filosofin. Cohen avslutar sin artikel med en lyrisk lovsång till den tysk-judiska enheten i stark patriotisk anda.?

Cohens lovsång till Tyskland är förståelig om man tänker på hans utgångspunkter som en ledande liberal filosof $\mathrm{i}$ sin tid. Men under de allra sista åren av sitt liv svalnade hans patriotism då han såg att antisemitismen snarare 
stärktes än försvagades av krigserfarenheterna. ${ }^{10} \mathrm{När}$ han dött bojkottade universitetet och vetenskapsakademin i Berlin - bägge befolkade av många antisemiter - hans begravning. Och i ljuset av vad som hände i Tyskland endast två decennier senare är hans idéer om en tysk-judisk gemenskap problematiska. Hans änka Martha - död i Theresienstadt I942 - hörde till offren för en tysk nationalism som förvandlats till demoni.

Eftervärldens dom över Cohens tyskvänlighet har också varit hård. Léon Poliakov skriver $\mathrm{i}$ sitt stora verk om antisemitismen historia om diskussionerna om tyskhet och judiskhet att det igen är Cohen "who wrote the most moving nonsense on the theme". ${ }^{11}$ Den framstående reformjudiske teologen Eugene B. Borowitz skriver om Cohens Tysklandsiver att även om man inte bör fästa alltför stor uppmärksamhet vid filosofers politiska ställningstaganden så gäller i detta fall att "the error is so blatant and the consequences so tragic". ${ }^{12}$

En annan betydande judisk tänkare, Emil Fackenheim ${ }^{13}$, diskuterar Cohens tyskvänlighet mer utförligt. Fackenheim visar förståelse för Cohens uppfattning eftersom denne som ingen jude före honom haft så stort inflytande på tyskt intellektuellt liv. Men det gör inte läsningen av vad Cohen skrev mindre smärtsam. Fackenheim betonar att när vi idag med facit $i$ hand kritiserar Cohen så gör vi det alltför lätt för oss. Hur skulle Cohen ha kunnat förutse Holocaust när inte ens vi som sett det ske kan förstå det? Fackenheim ursäktar vidare Cohen med att under krig är det många annars kloka personer som skriver mindre kloka ting: "... it is a melancholy fact that, during the First World War, the most foolish utterances were sincerely made by the greatest intellectuals in all the warring countries." Dessutom var Cohens handling inte ett uttryck för assimilatorisk feghet, utan för judiskt mod, vilket kritiken från de tysk-nationella visar. Cohens grundläggande misstag var, enligt Fackenheim, hans abstrakthet. För honom var Tyskland Kants, Goethes och Schillers land, inte det konkreta maktlystna reellt existerande Tyskland. ${ }^{14}$

\section{Martin Buber: omtänKaren}

För Martin Buber (1878-1965) blev första världskriget - med Joachim Israels ord - "en vändpunkt för den inriktning hans fortsatta skapande fick." ${ }^{15}$ Ett tydligt bevis på betydelsen av denna vändpunkt är att Buber i sitt testamente bestämde att ingenting opublicerat som var skrivet före I9I6 skulle få publiceras. $^{16}$

När kriget bröt ut 1914 ställde Buber sig solidarisk med Tyskland och uttalade sitt stöd för landets krigspolitik. Den inställningen delade han med sin 
lärare, sociologen Georg Simmel, och med majoriteten av Tysklands judar. Bubers biograf, Grete Schaeder, har beskrivit krigsutbrottets betydelse för Tysklands judar: det uppfattades som ett sista test, som de skulle bestå för att bevisa sin tyskhet och därmed undanröja all grund för antisemitism. ${ }^{17}$

I ett brev till sin vän Hans Kohn den 30.9 I9I4 skriver Buber hur ordet "folk" som aldrig förr blivit verklighet för honom. Han beklagar också att han inte själv kan delta vid fronten men deklarerar att han kommer att hjälpa till på sitt sätt. Sen tilläger han pompöst: "Für jeden, der in dieser Zeit sich aufsparen will, gilt das Wort des Evangelium Johannis: 'Wer sein Leben liebt, wird es verlieren.'"'18

Av en dagboksanteckning framgår det vari Bubers entusiasm över kriget bestod. Han hoppades att kriget skulle bidra till en förnyelse för centraleuropén, till ett uppvaknande för ryssen och till en semitisk pånyttfödelse i Mellanöstern, dvs. förverkligandet av en judisk stat. ${ }^{19}$ Det var inte kriget i sig utan upplevelsen (Erlebnis) som kriget medförde som skulle åstadkomma detta. Det var just Bubers Erlebnis-mystik som färgade hans syn på kriget. ${ }^{20}$

Bubers holländske vän, författaren och pacifisten Frederik van Eeden försökte få Buber att fördöma det tyska anfallet på Nederländerna. I sitt svar av den I6.IO I9I4 försvarar Buber Tyskland och hävdar att van Eedens beskrivning av händelsförloppet är fullt av halvsanningar. ${ }^{21}$ Han kritiserar vidare den oheliga allians som demokratierna England och Frankrike upprättat med Ryssland, "das stärkste Bollwerk der Gewaltherrschaft". Buber fortsätter att närmast lyriskt beskriva krigsstämningarna i Tyskland, där lugn, beslutsamhet och offervilja råder. I och med världskriget ser han en ny tid randas då människan når sin frihet genom att hon är villig att offra sig för det som har ett absolut värde. "Es ist eine furchtbare Gnade; es ist die Gnade der neuen Geburt."'22

Bubers mycket nära vän anarkisten Gustav Landauer hörde till de främsta krigsmotståndarna i Tyskland. Han blev mycket besviken på Bubers inställning till kriget och i ett brev av den I2.5 1916 kommer han med oerhört hård kritik av den syn på kriget som "Krigsbuber" gett uttryck för i Der Jude. Landauer kritiserar sin vän för officiös krigspolitisk retorik och säger sig uppfatta vissa uttalanden av Buber som "sehr schmerzlich, sehr widerwärtig und sehr nahe an der Unbegreifligkeit". ${ }^{23}$ Verklig Gemeinschaft - som Buber hoppas på - nås inte genom krig och patriotism, slår Landauer fast och deklarerar att han inte längre vill medverka i Der Jude, så länge dess redaktör stöder kriget. ${ }^{24}$

Det föreligger inget svar från Buber på Landauers brev men de två möttes flera gånger och det står klart att Buber påverkades av sin väns kritik. ${ }^{25}$ Att det fortsatta kriget inte medförde de positiva förändringar som Buber hoppades 
på och det faktum att den tyska antisemitismen inte upphörde trots judarnas stöd för kriget bidrog till en radikal omvärdering. Från och med nu förändras Bubers inställning till kriget, som han blir allt mer kritisk emot, och till nationalismen, vars faror och överdrifter han börjar varna för. I ett brev av den 4.2 I9I7 skriver han att han har övervunnit nationalismen ${ }^{26}$ och han börjar också kritisera överdriven nationalism inom den sionistiska rörelsen. ${ }^{27}$ Och i sin polemik med Hermann Cohen sommaren 1916 hävdar han med emfas att mänskligheten är förmer än staten och att det mer än någonsin är en plikt att säga det i dessa dagar. Samtidigt kritiserar han den europeiska "Scheinmenschlichkeit" som inte förmådde förhindra utbrottet av detta krig "aller gegen alle". ${ }^{28}$ Och i ett tal I9I8 kritiserar han i skarpa ordalag krigsprofitörerna, judiska och icke-judiska, och tillägger självrannsakande: "Und wer unter uns dürfte sich des Anteils an dieser Schuld entschlagen wollen?"29

Det står klart att Buber senare i livet inte var särskilt stolt över sin tidiga krigsentusiasm. När han utgav Landauers korrespondens lämnade han bort dennes kritiska brev av den I2.5 1916 och i den biografi som Hans Kohn under Bubers aktiva medverkan skrev ges en rätt så förskönad bild av Bubers inställning till första världskriget. ${ }^{30}$

Som redan nämnts blev upplevelserna under första världskriget av avgörande betydelse för Bubers tänkande. I Friedmans stora biografi heter kapitlet om kriget "The First World War and the Breakthrough to Dialogue". Krigserfarenheten blev en vändpunkt för Buber som förde honom från upplevelsemystik till det dialogiska tänkandet. Krigets vansinne klarlade för honom behovet av en äkta dialog, ett äkta möte mellan människor som respekterar varandra. Endast det - inga mystiska upplevelser - kan garantera fredlig samlevnad och en verklig gränsöverskridande gemenskap. "Begreppet 'Gemeinschaft' blir tillsammans med begreppet 'mellanmänsklig' och det på dialogen byggande autentiska mötet en kärnpunkt i den filosofiska utgångspunkt, som han just då höll på att utveckla. Även den mystiska upplevelsen underordnas det intersubjektiva mötet." 31

\section{Franz RosenzWEIG: SOLDATEN}

Av de personer vars inställning till första världskriget jag här undersöker är det endast Franz Rosenzweig (I886-1929) som själv deltog i kriget.

När kriget bröt ut i september I9I4 anslöt sig Rosenzweig till Röda Korsets tjänst i Betlin. Ännu samma månad sändes han som sanitär till Belgien. I april I9I5 gick han in som frivillig i den reguljära armén. Största delen av sin krigstjänst gjorde han som luftvärnsartillerist på Balkanfronten, men I9I8 deltog 
han också i en officerskurs i Rembertow nära Warszawa och vistades på militärsjukhus i Leipzig. I december r9r8 hemförlovades han och åtevände till Kassel. $^{32}$

I ett brev av den I4.4 I9I5 meddelar Rosenzweig sina föräldrar att han tänker gå in i armén. Han säger att han upplever det som sin plikt att ta detta steg och inte längre undfly fara genom att vara sjukskötare. "Gern tue ich es natürlich nicht, ich bin von Natur feige und werde für einen guten Soldaten viel zu nervös sein. Aber es musste sein." 33 Någon krigsivrare eller entusiastisk soldat var han alltså inte, men en person som kände plikt och ansvar för sitt fosterland. ${ }^{34}$

Under sin krigstjänst skrev Rosenzweig många brev, framför allt till sina föräldrar. Men det är mycket sällan som han kommenterar kriget på en mer allmän principiell nivå. Den 17.8 I916 skriver han att kriget inte är mindre etiskt eller religiöst än freden. Pacifismen är ett eländigt tänkesätt (verworfene Gesinnung) därför att den tror att gott och ont finns i de yttre omständigheterna, medan det i själva verket är mänskorna som är onda eller goda. Den religiösa fredsuppfattningen är eskatologisk: freden är ett resultat inte av mänskors utan av Guds handlande. ${ }^{35}$ Men ett år senare erkänner han att det finns en berättigad kärna i pacifismen: att övervinna nationalismen genom en statsfederation. ${ }^{36}$

Världskriget blev för Rosenzweig - liksom för Buber - av epokgörande betydelse. För honom innebar det uppgivande av rationalismen och anammandet av uppenbarelsen. "Världskriget framkallar hos honom en djup kris och ett radikalt brott med den rationalistiska filosofin, med historicismen och hegelianismen." ${ }^{37}$ Också upplevelserna vid fronten var betydelsefulla för Rosenzweig. I mars 1917 kommer han på Balkan första gången i kontakt med sefarder. Under sin vistelse i Rembartow möter han för första gången östjudar. Och den 22.8 I9I8 börjar han på Balkan skriva sitt stora verk Der Stern der Erlösung. Skrivandet sker på postkort som han skickar hem till sin mor. Boken slutförs efter att han hemförlovats och utkommer $1921 .^{38}$

När Rosenzweig efter en längre permission återvänder till fronten ger han den 23.7 I9I7 uttryck för stor krigströtthet och stark kritik av Tysklands krigspolitik. Vad angår mig detta krig som förs för Briegs eller Belgiens skull, frågar han och tillägger att han inte känner igen detta Tyskland. Sedan fortsätter han med att ironisera över tyska patrioter $\mathrm{i}$ allmänhet och pangermanisten Ernst zu Reventlow i synnerhet. 39

När kriget är slut och nederlaget ett faktum är han dock sorgsen. Han säger att han bevarat sin kyla när kriget bröt ut - då så många andra drogs med av krigshysteri - men att han nu upplever hur monarkistisk han egentligen är. Därför gör det ont att kejsaren abdikerat. "Ich will einen König." ${ }^{\circ 0}$ Den kris 
som det tyska sammabrottet förorsakade hos honom syns också i de delar av doktorsavhandlingen om Hegel - Vorwort och Schlussbemerkung - som han skrev efter kriget. ${ }^{41}$

Av det sparsamma materialet kan man ändå få fram en rätt tydlig bild av Rosenzweigs inställning till första världskriget. Han deltar av plikt. Han känner sig främmande för tillvaron som soldat och han har ingen sympati för Tysklands krigssyften. Det syns också av att han i början av kriget kom i strid med den av honom annars högt beundrade Hermann Cohen, vars inställning till kriget Rosenzweig ansåg vara chauvinistisk. ${ }^{42}$ Men liksom Cohen ville han gärna förena sin tyskhet och sin judiskhet. "Ich glaube, die Verjudung hat aus mir keinen schlechteren sondern einen besseren Deutschen gemacht." ${ }^{23}$ Därför var nederlaget svårt att bära också för honom.

\section{GERSHOM SCHOLEM: KRIGSMOTSTÅNDAREN}

Den store mästaren inom forskningen om judisk mystik, Gershom Scholem (1897-1982) - eller Gerhard som hans tyska namn var - var vid det första världskrigets utbrott en ung, men brådmogen man. Hans inställning till kriget var klar från första stund: han var emot det kompromisslöst och utan tvekan.

Scholem växte upp i en helt assimilerad judisk familj i Berlin. I stark opposition till sina föräldrar - han blev i ett skede utslängd hemifrån - blev han både medvetet judisk och sionist. Bland de tyska sionisterna hörde han till den yngre radikalare generation som kritiserade de etablerade sionisterna för ljumhet och halvdanhet och som i motsats till dessa inte bara ville verka för östjudisk emigration till Palestina utan själv planerade emigration.

Scholems judiska uppvaknande kom att bli avgörande inte bara för hans personliga och professionella liv utan också för hans inställning till världskriget. I och med denna omorientering vände han ryggen till den tyska nationalism som han upplevt så stark i sitt hem. När kriget närmade sig och krigshysterin steg till oanade höjder förblev han helt oberörd. Eller snarare tvärtom: han reagerade med avsky. Sina närmaste själsfränder hade han - efter deras möte 1915 - i Walter Benjamin och i den av sina tre bröder som stod honom närmast, den två år äldre Werner. Denne hörde till krigsmotståndarminoriteten inom det socialdemokratiska partiet, vilken hade samlats kring Rosa Luxemburg och Karl Liebknecht. Senare blev Werner kommunistisk riksdagsman och avrättades i Buchenwald I940. Tillsammans med Werner börjar den unge Scholem söka sig till socialistiska krigsmotståndarkretsar. Han hjälper till med att sprida deras material trots att han inte delar deras socialistiska grundsyn. ${ }^{44}$ 
Scholems krigsmotstånd var inte bara en åsikt som han lättvindigt höll sig med. Det var en djup övertygelse som han fick betala för. Våren I9Is blev han relegerad från gymnasiet p.g.a. en tidningsartikel som fördömde kriget och som skolledningen genom angiveri fătt kunskap om. ${ }^{45}$ En ny prövosten kom sommaren I9I7 då han inkallades till militären. I sina självbiografiska böcker är han mycket förtegen om varför han efter endast någon månad entledigades som "psykopat". ${ }^{6}$ I en intervju har han dock talat klarspråk: han simulerade mentalsjuk. ${ }^{47}$ Joseph Dan, som kände den gamle Scholem väl, har kommenterat: "This act never gave him any qualms nor did he express any misgivings." 48

Varför var Scholem en så absolut krigsmotståndare? Han säger själv att det inte var av pacifistiska skäl. Tvärtom ville han lära sig att använda gevär (uppenbarligen för att han trodde sig behöva den kunskapen i Palestina). ${ }^{49}$ Orsaken ligger $i$ hans totala avståndstagande från tysk nationalism. Som sionist upplevde han inte någon större plikt gentemot det land han råkade vara född i men som han redan bestämt sig för att lämna. ${ }^{50}$ Den tyska judenheten föraktade han p.g.a. dess assimilatoriska inriktning. Den mångomtalade fruktbara tysk-judiska symbiosen menade han att överhuvudtaget inte existerade. ${ }^{51}$

Den unge Scholems intellektuella vägval kännetecknades av en medveten rebelliskhet. ${ }^{52} \mathrm{Genom}$ att vägra låta sig dras med i den allmänna krigshysterin, genom att inte bara vara likgiltig men uttalat motsätta sig Tysklands krigspolitik ville han markera en konsekvent sionistisk hållning och dra en klar linje gentemot den tyska judenhet som han ansåg vara ideologiskt bankrutt.

\section{KONKLUSIONER}

De fyra stora tysk-judiska tänkare som vi undersökt uppvisar en inställning till första världskriget som omspänner hela fältet: Från Hermann Cohens extrema patriotism till Gershom Scholems absoluta avståndstagande. Kan vi se något mönster eller någon faktor som förklarar varför dessa kom att inta den åsikt de intog?

Det står helt klart att sionismen är en sådan faktor. Cohen var en deciderad motståndare till sionismen. Men han gick inte in för assimilation, utan ville bejaka sin tyskhet just som jude. Eftersom den antisemitism som fick ett uppsving på 1880-talet anklagade judarna för bristande lojalitet var det klart att Cohen och många andra judar med sin patriotism också ville visa att dessa anklagelser var ogrundade. Cohens patriotism var säkert inte bara instrumentell - ett medel för att visa lojalitet - utan helt äkta, men det är klart att det faktum att en uppvisad fosterlandkärlek kunde fungera som motgift mot 
antisemitismen också haft en viss betydelse. Scholem återigen ansåg sig inte behöva visa någonting för Tyskland. Han stod i beråd att lämna landet, han hade ideologiskt förkastat diasporan och den tyska judenhetens renommé var han inte intresserad av eftersom han betraktade denna judenhet med förakt. Cohens och Scholems ställningstagande är helt konsekventa med tanke på deras ideologiska inriktning.

När det gäller Rosenzweig är inte så mycket att säga. Liksom säkert de flesta tyska judar gjorde han sin plikt utan större entusiasm och utan att - åtminstone offentligt - ge uttryck för någon principiell hållning till kriget.

Bubers ställningstagande är det svåraste att förklara. Som sionist skulle han ha kunnat reagera som Scholem: det här kriget berör inte mig. Men till skillnad från Scholem hade Buber inte övergett Tyskland. Trots att han var sionist kände han säkert en stark lojalitet med Tyskland och med dess judar. Han stannade ju kvar i landet länge och emigrerade till Palestina först 1938.

Buber är tillsammans med Rosenzweig den för vilken kriget kom att betyda mest. Som vi har sett blev krigserfarenhet en viktig vändpunkt i bägges ideologiska utveckling. Också för Scholem var kriget betydelsefullt men då på det sättet att det befäste en övertygelse som han redan hade. Cohen dog innan kriget var slut så han hann aldrig göra någon retrospektiv uppgörelse med kriget och sin egen andel i det.

Det första världskrigets vansinne har uttryckts väl av Fackenheim: "If World War I was the War of Absurdity for Western democracy, for Jews it represented an absurdity that tore them apart. Patriotic Jews in both camps were fighting each other, and what is more, they were doing so in the name of Judaism." 53

\section{NoTER}

I. Författaren Göran Greider har talat om att arbetarrörelsens globala horisont "dog sommaren r9I4 när socialisterna gav efter för chauvinismen." (Greider, I3) Jfr. Nordin, 20: "Samtidigt med honom [Jean Jaurès] dog också den internationella socialistiska rörelse som Jaurès varit en av de mest prominenta företrädarna för."

2. När filosofen Eduard von Hartmann på i880-talet frågade om Tysklands judar i en valsituation skulle välja att rädda livet på en icke-judisk tysk eller på en jude som inte var tysk, gavs från judiskt håll svaret att valet naturligtvis skulle falla på ens tyska medbroder. (Fackenheim 1978, 150f.)

3. Två viktiga uttalanden av "protestrabbinerna" finns i engelsk översättning. i Mendes-Flohr \& Reinharz (Eds.), $538 f$.

4. Reinharz, 226-238. Munster (209-2Ix) räknar med tre grupperingar bland Tysklands judar vid denna tid.: förutom de assimilatoriskt inriktade och sionisterna också en tredje grupp av icke-sionistiska socialister med en större distans till det tyska. Munster 
erkänner dock att denna grupp - till vilken han räknar Gustav Landauer och Ernst Bloch var mycket liten.

5. Cohen 1907,255 . Se 254-257. Cohens vurmande för den tyska staten påverkades säkert av det faktum att han tillhörde den generation som upplevt den moderna tyska statens uppkomst genom Tysklands enande 1871. Om Cohens statsfilosoi, se Lübbe, 102-rr3.

6. Cohen $1924,229-236$.

7. Redan 1880 - då Cohens intresse för judiska frågor ännu var mycket sparsamt publicerade han en artikel, "Ein Bekenntnis in der Judenfrage" (a.a., 73-94), där han kritiserade historikern Heinrich von Treitschke för dennes teori om judendomens oförenlighet med det universalistiska moderna Tyskland.

8. A.a., 287 , se $237-301$. Nordin, 95 , kommenterar: "I hans [Cohens] lilla skrift om tyskhet och judendom var alla problem lösta. Varje motsättning mellan tyskt och judiskt hade utjämnats genom krigets kampgemenskap. Lika litet fanns någon motsatsställning mellan tyskt krig och evig fred i hela mänsklighetens intresse."

9. Cohen 1924, 302-318.

Io. I oktober 1916 beslöt krigsministeriet att genomföra en undersökning om hur många judar det fanns i krigstjänst. Orsaken var de allt tilltagande anklagelserna om att judarna smet undan och inte deltog i försvaret i lika stor utsträckning som den övriga befolkningen. (Poliakov, r48f.)

II. Poliakov, 139. Han tillägger dock att det stora flertalet av Tysklands judar vid denna tid i sak var rätt eniga med Cohen.

I2. Borowitz, 5I.

13. Fackenheim är född i Tyskland och satt 1938 en tid internerad i Sachsenhausen.

14. Fackenheim 1996, 42-46. Jfr. Fackenheim 1978, 183. Betydligt hårdare i sin dom över Cohen är Munster. Cohen bidrog med uppenbar naivitet till att skapa en ideologi för en pangermanistisk nyordning i Europa och till att bana vägen för en "nationell socialism". (Munster, 2I4f.) Bägge dessa syftar självfallet på nationalsocialismen och Tredje Riket.

15. Israel, 27. Jfr. Friedman, 202: "The real turning point in Buber's life that led to evergreater soberness and concreteness in walking the 'narrow ridge' was the First World War."

16. Friedman, 178 .

17. I Buber 1972,65 f.

I8. A.a., 37of.

19. Friedman, 197 .

20. Scholem har berättat hur Walter Benjamin vid denna tid ironiserade över Bubers upplevelsefilosofi genom att säga att man bör fråga varje jude: "Haben Sie schon das jüdische Etlebnis gehabt?" (Scholem 1975, 42)

21. Också ett drygt halvår senare, i ett annat brev till van Eeden I9.5 I9I5 (Buber 1972, 390), skriver Buber att han är av den åsikten att ingen människa kan säga hur sanningen om kriget ser ut.

22. A.a., 378 , se $374-380$.

23. A.a., 434 .

24. A.a., $436 f$.

25. Det märks också av att Landauer bara någon månad senare - $i$ ett brev av den 22.8 I9I6 - antyder att han igen vill medverka i Der Jude. (A.a., 45I.)

26. A.a., 470.

27. A.a., 525f. Jfr. 45I, samt vad han sade på den tolfte sionistkongressen I92I: "Der moderne Nationalismus läuft stets Gefahr, der Machthysterie zu verfallen, die die Abgrenzungsverantwortung zersetzt." (Buber I963, 3II) 
28. Buber 1963, 297.

29. Buber 1920,55 .

30. Flohr, 2r7f.

3I. Israel, 3rf. För en mer detaljerad analys av Bubers intellektuella utvecklingen under kriget, se Flohr.

32. Glatzer, 364 f.

33. Rosenzweig 1935, 89. Den 24.II 1916 skriver han till sina föräldrar att han tyvärr är en dålig soldat, opraktisk och fumlig. (A.a., I4I)

34. Den 3.91916 skriver han att han för sin del önskar att kriget tar slut när som helst. (A.a., Ir2)

35. A.a., I0o, jfr. I44f.

36. A.a., 245. Rosenzweig ser det eventuella positiva resultatet av kriget just $i$ att det kan befrämja uppkomsten av statsfederationer (Staatenverbänden). Jfr. Rosenzweig 1976, $370 f$. om kopplingen stat - krig, och 367f., där Rosenzweig hävdar att judarna är de enda egentliga "pacifisterna" eftersom de inte kan ta politiska krig på allvar då de känner begreppet krig för sin tro (Glaubenskrieg).

37. Löwy, 74 .

38. Att boken tillkommit i en skyttegrav är kanske orsaken till att den börjar med att behandla döden. "Vom Toden, von der Furcht des Todes, hebt alles Erkennen des All an." (Rosenzweig 1976, 3)

39. Den här utgjutelsen saknas i den tyska utgåvan av Rosenzweigs brev - utgiven 1935 - men finns i Glatzer, 57. En viss likgiltighet och bristande entusiasm för kriget gav han uttryck för också i ett brev i oktober 1916 (Rosenzweig 1935, 123f.).

40. Rosenzweig 1935, 351.

4I. För en analys av detta, se Avineri.

42. A.a., 292.

43. A.a., 474. Enligt Scholem (1976, 21) hävdade Rosenzweig i en privat diskussion att han inte kunde fortsätta att leva om han måste välja mellan tyskhet och judiskhet.

44. Scholem 1977, 7of.; Scholem 1975, 15. Scholem var däremot attraherad av anarkismen och var under kriget tidvis starkt påverkad av den tysk-judiske anarkisten och krigsmotståndaren Gutav Landauer. (Scholem $1977,71-73$; Scholem 1975, 14, I9f.)

45. Scholem 1977, 8of.; Scholem 1975, r4f.; Scholem 1976, r4f.

46. Scholem 1977, 124; Scholem 1975, 54, 59, 6I.

47. Scholem 1976,16 .

48. Dan, 6.

49. Scholem 1976,16 .

50. "If there was any one factor that caused Scholem to reject the war, it was his radical Zionism." (Biale, 6I) Scholem själv konfirmerar detta: hans broder motsatte sig kriget "for Socialist reasons, and I for Zionist reasons". (Scholem 1976, 13)

5I. Se, t.ex., Scholem 1976, 6I-92, jfr. I90f. I en intervju har Scholem medgett att frågan om tyskhet och judiskhet för honom var en negativ "obsession". (A.a., 2I)

52. Biale kallar den unge Scholem en enfant terrible (53), Dan kallar honom "a rebellious intellectual". (4)

53. Fackenheim 1978,183 . 


\section{LITTERATUR}

Avineri, Shlomo, 1988, "Rosenzweig's Hegel Interpretation: Its Relationship to the Development of His Jewish Reawakening" In: Wolfdietrich Scmied-Kowarzik (Hrsg.): Der Philosoph Franz Rosenzweig (1886-1929). Internationaler Kongress Kassel rg86. München

Biale, David, 1979, Gershom Scholem. Kabbalah and Counter-History. Cambridge, Mass. - London

Borowitz, Eugene B., I983, Choices in Modern Jewish Thought. A Partisan Guide. New York

Buber, Martin, 1920, Der heilige Weg. Ein Wort an die Juden und an die Völker. Frankfurt a.M.

Buber, Martin, 1963, Der Jude und sein Judentum. Gesammelte Aufsätze und Reden. Mit einer Einleitung von Robert Weltsch. Köln

Buber, Martin, 1972, Briefwechsel aus sieben Jahrzehnten. Band I: 1897-I918. Mit einem Geleitwort von Ernst Simon und einem biographischen Abriss als Einleitung von Grete Schaeder. Heidelberg

Cohen, Hermann, 1907, Ethik des reinen Willens. Zweite revidierte Auflage. Berlin

Cohen, Hermann, 1924, Jïdische Schriften. Zweiter Band. Zur jüdischen Zeitgeschichte. Mit einer Einleitung von Franz Rosenzweig herausgegeben von Bruno Strauss. Veröffentlichungen der Akademie für die Wissenschaft des Judentums. Berlin 1924

Dan, Joseph, 1988, Gershom Scholem and the Mystical Dimension of Jewish History. New York and London

Fackenheim, Emil L., 1978, The Jewish Return into History. Reflections in the Age of Auschwitz and a New Jerusalem. New York

Fackenheim, Emil L., I996, Jewish Philosopher and Jewish Philosophy. Edited by Michael L. Morgan, Bloomington and Indianapolis

Flohr, Paul R., 1975, "The Road to I and Thou. An Inquiery into Buber's Transition from Mysticism to Dialogue" In: Michael A. Fishbane - Paul R. Flohr (Eds.): Texts and Responses. Studies Presented to Nabum N. Glatzer on the Occasion of his Seventieth Birthday by bis Students. Leiden

Friedman, Maurice, 1981, Martin Buber's Life and Work. The Early Years 1878-1923. New York

Glatzer, Nahum N., 1953, Franz Rosenzweig: His Life and Thought. Philadelphia

Greider, Göran, 1999, "Vad gör vi nu då?" Arena 2/1999: Europabilaga "Vänsterns och demokratins Europa", 9-13

Israel, Joachim, 1992, Martin Buber. Dialogfilosof och sionist. Stockholm

Lübbe, Hermann, 1963, Politische Philosophie in Deutschland. Studien zu ihrer Geschichte. Basel/Stuttgart

Löwy, Michael, 1990, Förlossning och utopi. Översättning: Gustaf Gimdal. Göteborg Mendes-Flohr, Paul \& Reinharz, Jehuda (Eds.), I995, The Jew in the Modern World. A Documentary History. Second Edition. New York - Oxford

Munster, Arno, 1988, "Les intellectuels (philosophes) juifs-allemands face à la guerre de I9I4" In: Philippe Soulez (Ed.): Les Philosophes et la guerre de I4. Saint-Denis, 209-22I 
Nordin, Svante, 1998, Filosofernas krig. Den europeiska filosofin under första världskriget. Nora

Poliakov, Léon, 1985, The History of Anti-Semitism. Volume IV. Suicidal Europe, I8701933. Translated from the French by George Klin. The Litrman Library of Jewish Civilization. Oxford

Reinharz, Jehuda, 1975, "Consensus and Conflict Between Zionists and Liberals in Germany Before World War I" In: Michael A Fishbane and Paul R. Flohr (Eds.): Texts and Responses. Studies Presented to Nahum N. Glatzer on the Occasion of his Seventieth Birthday by his Students. Leiden

Rosenzweig, Franz, I935, Briefe. Unter Mitwirkung von Ernst Simon ausgewählt und herausgegeben von Edith Rosenzweig. Berlin

Rosenzweig, Franz, 1976, Der Mensch und sein Werk. Gesammelte Schriften II. Der Stern der Erlösung. 4. Auflage im Jahre der Schöpfung 5736 mit einer Einführung von Reinhold Mayer. Haag

Scholem, Gershom, 1975, Walter Benjamin - die Geschichte einer Freundschaft. Frankfurt am Main

Scholem, Gershom, 1976, On Jews and Judaism in Crisis. Selected Essays. Edited by Werner J. Dannhauser. New York

Scholem, Gershom, 1977, Von Berlin nach Jerusalem. Jugenderinnerungen. Frankfurt am Main

\section{SUMMARY}

The outbreak of World War I in 1914 was seen in Germany as the final test for its Jewry. The Jews had an opportunity to prove that they were good German citizens by acting as loyally and patriotically as the rest of the population and would thus, hopefully, make an end to German anti-Semitism.

This essay attempts to analyse the attitudes of four prominent German Jews to the war. Hermann Cohen appeared as a super-patriot appealing to the Jews of other countries for solidarity with Germany and trying to show the deep affinity between Germanism and Judaism. The fact that the patriotic reaction of German Jews did not eradicate anti-Semitism was a big disappointment for him.

Martin Buber first supported the German cause, but gradually grew more and more critical of it. The war came to signify a dramatic shift in his thinking: away from his earlier mystical thought to his insistence on dialogue. Franz Rosenzweig similarly experienced a great change. He developed away from rationalism and Hegelianism while serving in the German Army in the Balkans.

Gershom (Gerhard) Scholem was an opponent of the war from the very beginning. As a radical Zionist he despised German Jewry, which he considered to be ideologically bankrupt, and had no sympathies for the German cause or for the Jewish support of it. 